\title{
Analisis Internet Financial Reporting Index; Studi Komparasi Antara Perusahaan High-tech dan Non High-tech di Indonesia
}

\author{
Nadia Shelly Wardhanie \\ Program Studi Akuntansi FEB - Universitas Muhammadiyah Malang \\ Jl. Raya Tlogomas 246 Malang 65144. \\ E-mail: nadiashelly@ymail.com
}

\begin{abstract}
The purpose of this study was to compare the IFR disclosure between high-tech companies and non high-tech companies in Indonesia. IFR index consists of four components, namely content, timeliness, technology and user support. Object of this study were 19 high-tech companies and 19 non high-tech companies in Indonesia. These results indicate that there is no difference between the IFR disclosure between high-tech companies and non high-tech companies in Indonesia. the average number of IFR disclosure on high-tech company for 20.63 or $53 \%$, while the average non-disclosure in high-tech company for 18.37 or 47\%. Mann-Whitney test results to explain the test score Asymp. Sig. (2-tailed) is 0.529 indicates that there is no significant difference.
\end{abstract}

Key words: IFR, IFR index, High-tech companies, Non high-tech companies

\section{PENDAHULUAN}

Beberapa tahun terakhir penggunaan teknologi informasi mengalami peningkatan yang sangat pesat, salah satunya penggunaan media internet. Internet merupakan teknologi informasi yang memberikan fasilitas dan kemudahan, melalui media ini kita dapat memperoleh berbagai macam informasi yang dibutuhkan. Internet memiliki beberapa karakteristik dan keunggulan seperti mudah menyebar (pervasiveness), dan mempunyai interaksi yang tinggi (high interaction) (Asbaugh et al., 1999). Kemajuan teknologi informasi khususnya internet ditandai dengan meningkatnya jumlah pengguna internet di indonesia. Pada tahun 2010 total pengguna internet adalah 45 juta orang dan meningkat menjadi 50 juta orang pada semester pertama tahun 2011. Indonesia juga turut serta menyumbang jumlah pengguna internet dunia yaitu sebesar $8,5 \%$.

Dengan kemajuan teknologi informasi yang sangat pesat, internet mulai digunakan oleh sektor bisnis sebagai media komunikasi yang penting untuk memberikan informasi. Perkembangan tersebut telah mempengaruhi bentuk tradisional penyajian informasi perusahaan. Internet dipandang sebagai salah satu media pelaporan yang penting, sehingga informasi tentang kinerja perusahaan dapat dijangkau oleh seluruh investor secara global, selain melalui cara-cara tradisional, oleh berbagai pihak seperti kreditor, pemegang saham, dan analis (Ashbaugh et al., 1999). Internet semakin banyak digunakan sebagai sarana komunikasi khususnya dalam penyebaran informasi Akuntansi. Menurut Lymer et al. (1999) semakin banyak perusahaan yang telah menggunakan internet sebagai media untuk menyebarluaskan informasi Akuntansi. Hal ini didukung Xiao et al. (2004) yang menyebutkan bahwa internet menawarkan berbagai macam kemungkinan bagi perusahaan untuk melakukan pengungkapan informasi keuangan lebih baik dengan biaya yang lebih rasional serta dapat meraih

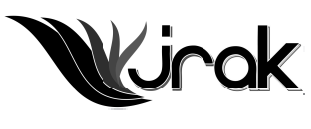

Jurnal Reviu Akuntansi dan Keuangan

ISSN: 2088-0685 Vol.2 No. 2, Oktober 2012 Pp 287-300 
Analisis

Internet... pengguna yang lebih luas tanpa keterbatasan secara geografis. Atas dasar penggunaan media internet sebagai sarana untuk memperoleh informasi keuangan maka muncullah suatu media pendukung penyajian laporan keuangan yaitu pelaporan keuangan melalui internet (Internet Financial Reporting-IFR).

Ashbaugh et al. (1999) menyatakan bahwa IFR dipandang sebagai alat komunikasi yang efektif kepada pelanggan, investor dan pemegang saham. IFR merupakan respon dari perusahaan untuk menjalin komunikasi dengan stakeholder, khususnya investor, dengan lebih baik dan lebih cepat. Jones (2002) dalam Abdelsalam et al. (2008) berpendapat bahwa "responsiveness" merupakan salah satu hal yang penting untuk meningkatkan kualitas komunikasi dan mempengaruhi kepercayaan investor pada pasar modal.

Lai et al. (2009) melakukan penelitian pertama yang mencoba menghubungkan antara IFR dengan saham. Lai menemukan bahwa perusahaan yang menerapkan IFR dan perusahaan dengan tingkat pengungkapan informasi yang tinggi cenderung mempunyai abnormal return yang lebih besar dan harga saham yang bergerak lebih cepat. Pada penelitian ini, Lai menggunakan Autoregresi dan Final Prediction Error untuk mengetahui kecepatan perubahan saham atas informasi baru dalam IFR.

Sedangkan Davey dan Homkajohn (2004) meneliti Corporate Internet $R e^{-}$ porting: An Asian Example, menggunakan indeks kualitatif yang dikembangkan oleh Cheng et al., (2000), dengan 4 kategori pengungkapan. Studi empiris tersebut dilakukan pada 40 perusahaan terbesar di Thailand. Dari hasil penelitian tersebut ditemukan bahwa kategori pengungkapan berkaitan dengan dukungan pengguna dan konten terbukti lebih tinggi daripada ketepatan waktu dan teknologi pada situs perusahaan Thailand.

Almilia (2009) melakukan penelitian tentang komparasi indeks IFR pada website perusahaan go public di indonesia dengan menggunakan sampel kelompok perusahaan LQ-45. Kelompok perusahan yang dikomparasikan adalah perbankan, LQ-45 serta Non Bank. Dari hasil penelitian menunjukkan bahwa banyak perusahaan yang belum memanfaatkan secara optimal sarana yang disediakan dalam website. Dari 343 perusahaan, hanya 213 perusahaan yang memiliki website dengan kualitas pengungkapan yang bervariasi. Namun pada industri perbankan, rata-rata indeks yang dimiliki lebih tinggi dibandingkan kelompok sampel lainnya.

Sedangkan Hargyantoro (2010) meneliti pengaruh IFR dan tingkat pengungkapan informasi website terhadap frekuensi perdagangan saham. Dengan menggunakan jumlah sampel 100 perusahaan yang masuk dalam kompas 100 tahun 2009 menunjukkan bahwa IFR dan tingkat pengungkapan website berpengaruh positif dan signifikan terhadap frekuensi perdagangan saham perusahaan. Dilihat dari informasi yang diungkapkan dapat memicu kenaikan transaksi investor.

Penelitian ini merupakan komparasi pengungkapan IFR Index antara perusahaan high-tech dan perusahaan non high-tech, dimana pengelompokkan perusahaan tersebut melihat perkembangan teknologi, internet merupakan salah satu teknologi baru dalam pelaporan keuangan perusahaan. Perusahaan yang tergolong dalam industri dengan penggunaan tingkat teknologi yang tinggi pada umumnya ingin menunjukkan kesadaran teknologi mereka melalui IFR sebagai salah satu cara untuk menarik para investor dan debitur. Tujuan penelitian ini adalah untuk mendeskripsi praktik pengungkapan laporan keuangan melalui internet oleh perusahaan serta mengkomparasikan pengungkapan IFR Index antara perusahaan high-tech dan non high-tech.

\section{PENGEMBANGAN HIPOTESIS}

Dalam menghadapi perubahan dalam teknologi, internet merupakan salah satu teknologi baru dalam pelaporan keuangan perusahaan. Indikator pengelompokkan industri berdasarkan high-tech dan non high-tech adalah adanya 
pengungkapan biaya penelitian dan pengembangan (Research and Development) pada laporan keuangan perusahaan. Perusahaan yang tergolong dalam industri dengan penggunaan tingkat teknologi yang tinggi pada umumnya ingin menunjukkan kesadaran teknologi mereka melalui IFR sebagai salah satu cara untuk menarik para investor dan debitur. Dalam penelitian yang dilakukan oleh Williams (2001) mengkategorikan jenis industri (Industry Type) berdasarkan ada tidaknya pengungkapan biaya penelitian dan pengembangan pada laporan keuangan.

Silva dan Alves (2004) dalam penelitian mereka tentang The Voluntary Disclosure of Financial Information on the Internet and the Firm Value Effect in Companies Across Latin America menyatakan bahwa hasil dari penelitian mereka terhadap 150 perusahaan di Amerika Latin dengan 4 sektor yang berbeda menunjukkan adanya kecenderungan untuk melakukan pengungkapan sukarela terhadap laporan keuangan mereka melalui internet.

Dengan demikian jenis industri yang terdiri dari perusahaan high-tech dan non high-tech cenderung berbeda dalam menerapkan praktik IFR. Sehingga hipotesis yang diajukan sebagai berikut:

H1: Terdapat perbedaan yang signifikan antara IFR Index perusahaan high-tech dan IFR Index perusahaan non high-tech di Indonesia

H0: Tidak terdapat perbedaan yang signifikan antara IFR Index perusahaan hightech dan IFR Index perusahaan non high-tech di Indonesia

\section{METODA PENELITIAN}

\section{Objek Penelitian}

Objek penelitian ini diambil dari perusahaan yang termasuk dalam kategori perusahaan terkemuka di pasar permodalan di Indonesia tahun 2011 . Penelitian ini menggunakan 38 perusahaan dengan nilai kapitalisasi tertinggi di Indonesia menurut IDX Fact Book tahun 2011. IDX Fact Book merupakan salah satu penilaian yang dilakukan oleh Indonesia Stock Exchange mengenai perusahaan-perusahaan go public berdasarkan nilai kapitalisasi pasar yang dimilikinya. Nilai Kapitalisasi pasar merupakan cerminan nilai perusahaan yang dihitung dari harga pasar dikalikan dengan jumlah saham yang diterbitkan/ outstanding shares.

\section{Jenis dan Sumber Data}

a. Jenis Data

Data yang digunakan dalam penelitian ini adalah data sekunder, yaitu data yang diperoleh/dikumpulkan dan disatukan oleh studi-studi sebelumnya atau yang diterbitkan oleh berbagai instansi terkait. Data sekunder yang digunakan dalam penelitian ini adalah informasi keuangan dan non keuangan yang meliputi:
1) Laporan Kuartal Pertama Tahun 2011
2) Annual Report Tahun 2010
3) Daftar perusahaan dengan kapitalisasi pasar terbesar
4) Data lain yang terdapat dalam situs web perusahaan

b. Sumber Data

Data-data yang digunakan dalam penelitian ini, merupakan data-data yang bersumber dari Sumber data penelitian ini diperoleh dari:
1) Indonesia Stock Exchange (IDX) Fact 2010-2011
2) Bursa Efek Indonesia (BEI)
3) Situs perusahaan
4) Buku teks, artikel dan penelitian terdahulu yang terkait dengan penelitian.


Analisis

Internet...

\section{Teknik Perolehan Data} metode:

Dalam penelitian ini pengumpulan data dilakukan dengan beberapa

a. Dokumentasi pada Indonesia Stock Exchange (IDX) Fact 2011 untuk memperoleh daftar leading companies di pasar modal selama tahun 2011.

b. Observasi situs web perusahaan dengan tahap- tahap:

1) Melihat alamat situs web perusahaan yang tercantum dalam Indonesia Stock Exchange (IDX) Fact 2011.

2) Situs web perusahaan yang tidak tercantum dalam IDX Fact, peneliti menggunakan search engine yang umum digunakan seperti Google dan Yahoo.

3) Situs web perusahaan diakses untuk menguji aksesbilitasnya dan untuk keperluan pengumpulan data.

Apabila tidak ditemukan situs web melalui IDX Fact dan search engine, maka perusahaan dianggap tidak mempunyai situs.

\section{Pengukuran Variabel}

Variabel yang digunakan dalam penelitian ini adalah official website perusahaan yang termasuk dalam kategori perusahaan terkemuka di pasar permodalan di Indonesia tahun 2011di Indonesia. Komponen IFR yang digunakan sebagai unit analisis dalam penelitian ini yaitu:

1) Informasi Keuangan Perusahaan yang terdiri dari:

a. Laporan posisi keuangan

b. Laporan kinerja keuangan

c. Laporan arus kas

d. Laporan perubahan ekuitas

e. Financial Highlight

f. Laporan pimpinan perusahaan

g. Laporan Auditor

h. Informasi pemegang saham

i. Informasi perusahaan

j. Tanggung jawab sosial perusahaan

k. Laporan tahunan

l. Laporan triwulan

m. Grafik harga saham

2) Ketepatan waktu, antara lain:

a. Siaran pers

b. Hasil triwulan terbaru yang telah diaudit

c. Harga saham

d. Pernyataan visi perusahaan/ pernyataan perkiraan masa depan

3) Penggunaan Teknologi, antara lain:

a. Download plug-in

b. Online feedback

c. Slide presentasi

d. Teknologi multimedia

e. Alat analisis

f. Fitur Canggih (XBRL) 
4) Dukungan pengguna, antara lain:

a. Help \& FAQ

b. Link ke halaman utama

c. Link ke atas

d. Situs peta (site map)

e. Situs pencari

Sedangkan IFR Index diukur dengan menggunakan skala dummy yang dibuat dalam bentuk checklist. Jawaban ya diberi skor 1 dan jawaban tidak diberi skor 0 . Terdapat beberapa sub komponen yang menggunakan multiplier skor yaitu 2 dan 3. Pengukuran dilakukan pada komponen-komponen antara lain:

a. laporan keuangan (content)

Isi laporan keuangan memiliki kriteria penilaian sebesar 40\%. Jika informasi keuangan diungkapkan dengan format HTML maka skor yang dinilai lebih tinggi yaitu 2 poin dibandingkan dalam format PDF yaitu 1 poin. Hal ini disebabkan format PDF membutuhkan program pendukung yaitu Adobe Acrobat Reader untuk membaca dan mencetak file yang mana program tersebut tidak selalu tersedia. Sedangkan format HTML menggunakan konsep hypertext yang mendukung navigasi melalui link di setiap halaman dan tidak membutuhkan program pendukung dalam kegiatan aksesnya sehingga penggunaan tekonologi web berupa format HTML lebih memudahkan pengguna untuk mengakses informasi keuangan secara efektif dan cepat. Skor maksimal yang akan diberikan adalah 50 .

b. Waktu pelaporan keuangan (timeliness)

Waktu pelaporan keuangan memiliki kriteria penilaian sebesar $20 \%$. Untuk pengungkapan siaran pers dan harga saham, terdapat nilai tambah bagi informasi baru (pada skala 0 sampai 3) yang diukur dari jangka waktu diperbaruinya. Perusahaan juga menerima skor untuk pengungkapan hasil triwulan terbaru yang telah diaudit dan pernyataan visi perusahaan/ pernyataan perkiraan masa depan. Skor maksimal yang akan diberikan adalah 17.

c. Teknologi yang digunakan (techonology index)

Teknologi yang digunakan memiliki kriteria penilaian sebesar $20 \%$. Teknologi yang digunakan meliputi item-item yang tidak dapat disediakan oleh laporan tercetak antara lain download plug-in, umpan balik secara online, penggunaan slide presentasi, penggunaan teknologi multimedia (audio dan video), alat analisis dan fitur yang canggih (misalnya XBRL). Skor maksimal yang akan diberikan adalah 18.

d. Fasilitas pendukung web (user support)

Para pengguna memiliki ketrampilan berbeda dalam mengoperasikan komputer diantaranya pemula hingga ahli. Perusahaan yang menerapkan alat yang mana memfasilitasi pengguna IFR mendapatkan skor lebih tinggi. Teknologi yang digunakan memiliki kriteria penilaian sebesar 20\%. Alat-alat yang dinilai dalam indeks antara lain pencarian dan alat navigasi (seperti $F A Q$, Link ke halaman utama, Link ke atas, Situs peta, Situs pencari), jumlah klik untuk mendapatkan informasi keuangan (pada skala 0 sampai 3), serta konsistensi desain halaman web. Skor maksimal yang akan diberikan adalah 15 .

Sehingga penilaian skor indeks pelaporan keuangan melalui internet secara matematis menurut Agyei-Mensah (2010) yang dikembangkan oleh Almilia (2008) dapat dihitung dengan: 


$$
I R I=\frac{T D}{M}=\frac{\sum_{1}^{m} d i}{\sum_{1}^{n} d i}
$$

\section{Dimana:}

$$
\text { IRI = Internet Reporting Index (Indeks Pelaporan Internet) }
$$

$\mathrm{TD}=$ Total skor pengungkapan

$\mathrm{M}$ = Skor maksimum pengungkapan masing-masing perusahaan

$\mathrm{di}=$ Item pengungkapan $\mathrm{i}$

$\mathrm{m}=$ Jumlah aktual item pengungkapan yang relevan

$\mathrm{n}$ = Jumlah item yang diperkirakan akan diungkapkan

Atau dapat disimpulkan menjadi:

$$
I R I=\frac{\text { Total item yang diungkapkan }}{\text { Total item yang mungkin diungkapkan }}
$$

\section{Teknik Analisis Data}

Setelah data dikumpulkan, maka langkah selanjutnya adalah menganalisis data. Pada tahap ini, data diolah dan dimanfaatkan sedemikian rupa sehingga pada akhirnya dapat menyimpulkan kebenaran yang dapat dipakai untuk menjawab permasalahan yang diajukan dalam penelitian.

Berikut tahapan analisis data yang dilakukan dalam penelitian ini:

a. Analisis Isi

Analisis isi bersifat pembahasan secara mendalam terhadap isi suatu informasi tertulis situs web. Tahapan yang akan dilakukan adalah mengklasifikasi infor masi IFR kedalam komponen instrumen pengungkapan IFR yaitu isi, ketepatan waktu, teknologi yang digunakan, dan dukungan pengguna pada perusahaan dan memberi tanda check list pada komponen pengungkapan IFR.

b. Melakukan pengukuran IFR Index (variabel dependen);

Pengukuran IFR Index menggunakan alat pengungkapan IFR (IFR Disclosure Instruments). Setelah itu dilakukan penjumlahan sub-komponen pengungkapan pada perusahaan. Penjumlahan item pengungkapan dikategorikan dalam empat komponen yaitu, isi, ketepatan waktu, teknologi yang digunakan dan dukungan pengguna.

c. Mengklasifikasikan perusahaan high-tech dan non high-tech;

Indikator pengelompokkan jenis industri berdasarkan teknologi tinggi dan teknologi rendah adalah adanya pengungkapan biaya penelitian dan pengembangan (Research and Development) pada laporan keuangan perusahaan.

d. Uji Beda (Uji T)

Pengujian dilakukan untuk mengetahui adanya perbedaan jumlah item IFR yang diungkapkan antara perusahaan high-tech dan perusahaan non hightech.

\section{HASIL DAN PEMBAHASAN}

Berikut ini hasil analisis data yang dilakukan menggunakan aplikasi SPSS 16, dengan tahapan-tahapan:

\section{Analisis Isi}

IFR dapat diidentifikasi dengan melakukan analisis isi ( content analysis) yaitu melakukan penelitian secara mendalam terhadap isi situs web serta informasi yang 
diungkapkan oleh perusahaan. Analisis isi dapat dilakukan dengan menggunakan instrumen/alat pengungkapan IFR yang terdiri dari empat komponen. Informasi yang telah diungkapkan dalam situs web diklasifikasikan ke dalam empat komponen tersebut antara lain isi, ketepatan waktu pelaporan, teknologi yang digunakan dan dukungan pengguna.

Analisis isi diawali dengan melihat situs web perusahaan yang tercantum dalam Indonesia Stock Exchange (IDX) Fact 2011. Jika terdapat situs web perusahaan yang tidak tercantum maka peneliti menggunakan search engine untuk mencari alamat situs web tersebut. Selanjutnya, peneliti mengkases situs web perusahaan yang sudah diperoleh untuk menguji aksesbilitasnya. Peneliti melakukan akses situs web peruahaan pada tanggal 28 Oktober 2011 hingga 24 Desember 2011. Setelah teruji aksesbilitasnya, peneliti melakukan investigasi pada masingmasing situs web satu per satu dan menelusuri secara menyeluruh setiap link yang terdapat dalam situs web dengan frekuensi mengunjungi sebanyak dua hingga empat kali. Data-data mengenai informasi IFR yang diperoleh selanjutnya diklasifikasi dalam komponen instrumen pengungkapan IFR antara lain isi, ketepatan waktu, teknologi yang digunakan dan dukungan pengguna. Dalam komponen-komponen juga terdapat beberapa item tertentu.

\section{Pengukuran Indeks IFR}

Informasi IFR yang telah diklasifikasikan lalu diukur dengan menggunakan alat pengungkapan IFR (IFR Disclosure Instruments) berupa skala dummy. Apabila item dalam komponen tersebut diungkapkan maka diberi skor 1. Namun apabila tidak diungkapkan maka diberi skor 0 . Untuk item yang telah diungkapkan, jika disajikan dengan format PDF maka diberi skor 1 dan jika dengan format HTML maka diberi skor 2 .

Selanjutnya skor dari item-item tersebut dijumlahkan dan diberi prosentase sesuai dengan kategori masing-masing komponen antara lain sebagai berikut:

\section{a. Isi/Konten}

Komponen pertama yang terdapat dalam pengungkapan IFR adalah terkait isi/konten situs web antara lain pada tabel 1 berikut:

\begin{tabular}{ccc}
\hline Skor & No. Perusahaan & \% Sampel \\
\hline $41-50$ & 2 & $5,3 \%$ \\
$31-40$ & 2 & $5,3 \%$ \\
$21-30$ & 31 & $81,6 \%$ \\
$11-20$ & 2 & $5,3 \%$ \\
$0-10$ & 1 & $2,6 \%$ \\
\hline
\end{tabular}

Dari checklist yang telah dilakukan pada lampiran 1, diketahui bahwa dari seluruh perusahaan, 37 perusahaan $(97,4 \%)$ telah mengungkapkan laporan keuangan secara lengkap di dalam situs web perusahaan dengan format yang berbeda. Laporan keuangan secara lengkap terdiri dari laporan posisi keuangan, laporan kinerja keuangan, laporan arus kas, laporan perubahan ekuitas, dan catatan atas laporan keuangan. Dua diantaranya $(4,17 \%)$ mengungkapkan laporan keuangan dalam format PDF maupun HTML (lampiran 2). Laporan pimpinan, laporan auditor serta informasi yang berkaitan dengan perusahaan dan stakeholder juga termasuk dalam laporan keuangan yang diungkapkan dalam situs web. Sebanyak 28 perusahaan (71,75\%) juga mengungkapkan grafik saham dalam format HTML. Sedangkan hanya dua perusahaan $(4,16 \%)$ yang tidak mencantumkan alamat perusahaan dalam situs web.

Tabel 1

Skor Pegungkapan Isi/Konten 
Analisis

Internet...

\section{4}

Tabel 2

Skor Pengungkapan

Waktu Pelaporan

Informasi
Seluruh perusahaan mengungkapkan informasi keuangan menggunakan versi bahasa Indonesia dan terdapat 46 perusahaan $(95,83 \%)$ yang telah menggunakan versi dua bahasa yaitu bahasa Indonesia dan bahasa inggris. Namun termasuk juga 1 perusahaan $(2,08 \%)$ yang telah menggunakan versi lima bahasa dalam mengungkapkan informasi keuangannya dalam situs web (lampiran 3).

b. Waktu Pelaporan Keuangan

Jumlah perusahaan yang memberikan informasi berdasar ketepatan waktu dalam situs web mereka disajikan dalam tabel 2 sebagai berikut:

\begin{tabular}{lcc}
\hline Ketepatan Waktu & No. & Perusahaan \\
\hline Siaran Pers & 34 & $89 \%$ \\
LaporanTriwulan Terbaru Belum & & \\
Diaudit & 34 & $89 \%$ \\
Penawaran Saham & 32 & $84 \%$ \\
Pernyataan Visi & & \\
Keberadaan & 29 & $76 \%$ \\
Disclaimer & 1 & $3 \%$ \\
Grafik & 3 & $8 \%$ \\
\hline
\end{tabular}

Dalam checklist pada lampiran 4 dapat diketahu bahwa item yang paling sering muncul dalam pengungkapan diatas adalah siaran pers dan laporan triwulan di 34 perusahaan atau $89 \%$ situs web perusahaan. Pada umumnya perusahaan mengungkapkan siaran pers untuk menunjukkan update informasi tentang perusahaan serta laporan triwulan yang rutin diperbarui pengungkapannya melalui media web. Selain itu perusahaan mengungkapkan informasi mengenai penawaran saham. Dalam penawaran saham, perusahaan mengungkapkan perkembangan harga pasar saham serta kegiatan pertukaran saham menurut tanggal investasi yang rutin diperbarui baik secara per jam, harian, hingga mingguan.

Item terakhir dalam komponen waktu pelaporan adalah pernyataan visi. Hal ini diungkapkan oleh 29 perusahaan (76\%) dalam bentuk pernyataan deskriptif. Grafik perkiraan keuntungan masa depan/tren telah diungkapkan tiga perusahaan (8\%) dalam bentuk grafik EPS, prospek usaha maupun perkiraan laba yang dapat dilihat di lampiran 5. Sedangkan pernyataan disclaimer hanya diungkapkan pada satu perusahaan (3\%) saja (lampiran 6). Hal ini disebabkan karena perusahaan kurang memperhatikan kalangan pengguna IFR yang heterogen, sehingga menganggap kurang diperlukannya pengungkapan disclaimer di dalam situs web.

c. Teknologi

Item komponen ini berkaitan dengan pemanfaatan teknologi yang tidak dapat disediakan oleh media cetak serta teknologi multimedia yang digunakan dalam situs web perusahaan. Jumlah perusahaan yang menggunakan item teknologi dalam situs web terdapat dalam lampiran 7 sehingga diperoleh skor sebagai berikut: 


\begin{tabular}{lcc}
\hline \multicolumn{1}{c}{ Teknologi } & No. & Perusahaan \\
\hline Download Plug-in & 2 & $5 \%$ \\
Umpan Balik Secara Online & 9 & $24 \%$ \\
Penggunaan Slide Presentasi & 34 & $89 \%$ \\
Penggunaan Teknologi Multimedia & 16 & $42 \%$ \\
Alat Analisis & 5 & $13 \%$ \\
Fitur Canggih (XBRL) & 0 & $0 \%$ \\
\hline
\end{tabular}

Dapat dilihat bahwa hanya 2 perusahaan (5\%) menyediakan download plugin seperti install plugin flash player bagi situs web perusahaan yang menampilkan video (lampiran 8). Beberapa perusahaan telah menyediakan kontak e-mail yang bertujuan sebagai media umpan balik antara pengguna IFR dan perusahaan. Terdapat 9 perusahaan (24\%) memiliki kontak e-mail yang langsung terhubung secara online. Selain kontak e-mail, terdapat perusahaan memiliki layanan 24 jam secara online serta request information di dalam situs web mereka.

Perusahaan yang menggunakan slide presentasi dan mengungkapkannya dalam situs web adalah sebanyak 34 perusahaan (89\%). Slide presentasi pada umumnya diungkapkan pada presentasi korporasi, presentasi analis yang berisi tinjauan keuangan, tinjauan operasional dan tinjauan komersial dalam bentuk PDF.

Selain itu perusahaan yang menggunakan teknologi multimedia dalam situs web adalah sebanyak 16 perusahaan (42\%) berupa klip iklan, video profil perusahaan maupun galeri foto. Sedangkan alat analisis yang tersedia dalam situs web seperti auto chart dan online tools telah disediakan oleh 5 perusahaan $(13 \%)$.

Lain halnya dengan XBRL (Extensible Bussiness Reporting Language), tidak ada perusahaan yang menggunakan program XBRL dalam situs webnya.

d. Dukungan Pengguna

Dukungan penggunaan dapat menunjukkan bahwa perusahaan menerapkan alat yang mana memfasilitasi pengguna situs web. Item dan jumlah perusahaan yang menyediakan fasilitas dukungan pengguna dalam situs web disajikan dalam tabel 4

\begin{tabular}{lcc}
\hline \multicolumn{1}{c}{ Teknologi } & No. & Perusahaan \\
\hline Bantuan \& FAQ & 15 & $39 \%$ \\
Link Ke Beranda & 34 & $100 \%$ \\
Link Ke Bagian Teratas & 5 & $13 \%$ \\
Peta Situs & 30 & $79 \%$ \\
Situs Pencarian & 34 & $89 \%$ \\
\hline
\end{tabular}

Tabel 4

Skor Fasilitas Pendukung Web
Tabel 3

Skor Pemanfaatan Teknologi Dalam Situs Web 
Analisis

Internet...
Dilihat dari checklist pada lampiran 9, item bantuan \& FAQ diungkapkan dalam situs web bertujuan untuk megurangi jumlah e-mail yang dikirim ke perusahaan, namun perusahaan yang memanfaatkan fasilitas tersebut hanya sebanyak 15 perusahaan (39\%). Sedangkan seluruhnya atau sebanyak $100 \%$ perusahaan memiliki link ke beranda dalam situs web mereka. Berbeda dengan link ke beranda, perusahaan yang menyediakan link ke atas dalam situs web mereka hanya $13 \%$ atau sebanyak 5 perusahaan.

Sebuah peta situs sangat berguna untuk menunjukkan struktur dari situs web perusahaan hanya pada satu halaman sehingga dapat mempermudah akses yang dilakukan pada situs web tersebut. Terdapat 30 perusahaan $(79 \%)$ yang menyediakan peta situs di situs web mereka. Hal ini serupa dengan situs pencarian yang tersedia di dalam situs web, 34 perusahaan (89\%) menyediakan alat pencarian tersebut yang biasanya ditampilkan di halaman beranda web.

Dari perhitungan diatas, maka dapat diperoleh data penilaian indeks pelaporan keuangan melalui internet yang berasal dari skor keempat komponen pengungkapan IFR secara matematis dapat dihitung dengan:

$I R I=\frac{T D}{M}=\frac{\sum_{1}^{m} d i}{\sum_{1}^{n} d i}$

Dimana:

IRI = Internet Reporting Index (Indeks Pelaporan Internet)

TD = Total skor pengungkapan

$\mathrm{M}$ = Skor maksimum pengungkapan masing-masing perusahaan

di = Item pengungkapan $\mathrm{i}$

$\mathrm{m}=$ Jumlah aktual item pengungkapan yang relevan

$\mathrm{n} \quad=$ Jumlah item yang diperkirakan akan diungkapkan

Atau dapat disimpulkan menjadi:

IRI $=\frac{\text { Total item yang diungkapkan }}{\text { Total item yang mungkin diungkapkan }}$

Dapat dilihat dari tabel diatas bahwa rata-rata hasil perhitungan total Indeks IFR adalah 51\%. Dari 38 perusahaan yang diambil sebagai sampel, terdapat 21 perusahaan atau $55,26 \%$ dari sampel yang melakukan praktek IFR, selebihnya yaitu 17 perusahaan $(44,74 \%)$ melakukan praktek IFR dibawah rata-rata. Hasil pengukuran tersebut telah didasarkan pada item-item yang ada pada IFR Indeks. Dapat dilihat bahwa kriteria pelaporan yang presentasinya paling rendah adalah teknologi. Hal ini dikarenakan setiap perusahaan masih melakukan praktek IFR secara maksimal pada komponen isi/konten saja.

\section{Pengklasifikasian perusahaan high-tech dan non high-tech}

Setelah diketahui IFR Disclosure Scores, peneliti mengklasifikasikan perusahaan-perusahaan dalam perusahaan high-tech dan non high-tech. Dalam pengklasifikasian perusahaan antara high-tech dan non high-tech pada dasarnya dilihat dari indikator adanya pengungkapan biaya penelitian dan pengembangan (Research and Development) pada laporan keuangan perusahaan. Dalam penelitian yang dilakukan oleh Williams (2001) mengkategorikan jenis industri (Industry Type) berdasarkan ada tidaknya pengungkapan biaya penelitian dan pengembangan 
pada laporan keuangan. Dengan demikian jenis industri memiliki pengaruh terhadap keputusan perusahaan dalam menerapkan praktik IFR.

Diantara 38 perusahaan yang diteliti, terdapat 19 perusahaan high-tech yang mengungkapkan biaya-biaya yang berkaitan dengan penelitian dan pengembangan seperti biaya pengembangan software, biaya pengembangan karyawan, biaya penelitian sisa cadangan dan sebagainya.

Sedangkan terdapat 19 perusahaan yang termasuk non high-tech karena dalam laporan keuangan perusahaan seperti laporan laba rugi komersial tidak terdapat biaya yang berkaitan dengan penelitian dan pengembangan.

\section{Uji T}

Pada penelitian ini digunakan uji $\mathrm{T}$ yaitu uji beda 2 rata-rata (independent samples $T$ test) untuk melihat perbandingan pengungkapan IFR pada official website antara perusahaan high-tech dan perusahaan non high-tech di Indonesia.

\begin{tabular}{llcccc}
\hline & PERUSAHAAN & N & Mean & Std. Deviation & Std. Error Mean \\
\hline IFR INDEX & HIGH-TECH & 19 & .5116 & .11490 & .02636 \\
\cline { 3 - 5 } & NON HIGH-TECH & 19 & .5142 & .09489 & .02177 \\
\hline
\end{tabular}

Tabel 5.

Hasil Uji Rata-Rata Group Statistics

Tabel 5 diatas menggambarkan rata-rata pengungkapan IFR pada perusahaan high-tech lebih tinggi jika dibandingkan dengan perusahaan non high-tech. Hal ini dibuktikan dengan jumlah rata-rata pengungkapan IFR Index pada perusahaan high-tech sebesar 0,5116 sedangkan rata-rata pengungkapan pada perusahaan non high-tech sebesar 0,5142.

\begin{tabular}{|c|c|c|c|c|c|c|c|c|c|c|}
\hline & \multicolumn{2}{|c|}{$\begin{array}{c}\text { Levene's Test for } \\
\text { Equality of } \\
\text { Variances }\end{array}$} & \multicolumn{7}{|c|}{ t-test for Equality of Means } \\
\hline & & \multirow[b]{2}{*}{$\mathrm{F}$} & \multirow[b]{2}{*}{ Sig. } & \multirow[b]{2}{*}{$\mathrm{t}$} & \multirow[b]{2}{*}{$\mathrm{df}$} & \multirow{2}{*}{$\begin{array}{l}\text { Sig. (2- } \\
\text { tailed) }\end{array}$} & \multirow{2}{*}{$\begin{array}{c}\text { Mean } \\
\text { Difference }\end{array}$} & \multirow{2}{*}{$\begin{array}{l}\text { Std. Error } \\
\text { Difference }\end{array}$} & \multicolumn{2}{|c|}{$\begin{array}{l}\text { 95\% Confidence } \\
\text { Interval of the } \\
\text { Difference }\end{array}$} \\
\hline & & & & & & & & & Lower & Upper \\
\hline \begin{tabular}{|l} 
IFR \\
INDEX
\end{tabular} & $\begin{array}{l}\text { Equal } \\
\text { variances } \\
\text { assumed }\end{array}$ & .001 & .975 & -.077 & 36 & .939 & -.00263 & .03419 & -.07197 & .06670 \\
\hline & $\begin{array}{l}\text { Equal } \\
\text { variances not } \\
\text { assumed }\end{array}$ & & & -.077 & 34.757 & .939 & -.00263 & .03419 & -.07205 & .06679 \\
\hline
\end{tabular}

Tabel 6.

Hasil Uji Statistik T Independent Samples Test

Dalam pengujian hipotesis ini digunakan uji T karena uji T merupakan bagian uji beda (compare means test). Berdasarkan tabel 10 diketahui bahwa besarnya nilai T hitung (equal variance assumed) adalah -0,077. Nilai Asymp. Sig. (2-tailed) pada penelitian ini yaitu 0,939 . Hasil yang diperoleh untuk $T$ tabel pada signifikansi 0,05:2 = 0,025 (uji 2 sisi) dengan derajat kebebasan (df) 38-2 $=36$ sebesar $-2,028$ sehingga nilai $-t$ hitung $>-t$ tabel $(-0,077>-2,028)$ dan signifikansi $>0,005$ maka H0 diterima. Jadi, dapat disimpulkan bahwa pengungkapan IFR antara perusahaan high-tech dan perusahaan non high-tech tidak terdapat perbedaan yang signifikan. 
Analisis

Internet...

\section{PEMBAHASAN}

Objek penelitian ini diambil dari perusahaan yang termasuk dalam kategori perusahaan terkemuka di pasar permodalan di Indonesia tahun 2011 . Penelitian ini menggunakan 38 perusahaan dengan nilai kapitalisasi tertinggi di Indonesia menurut IDX Fact Book tahun 2011 dan memiliki situs web resmi yang dapat diakses. Sedangkan data yang digunakan pada peneletian ini adalah seluruh informasi keuangan yang telah diungkapkan oleh perusahaan dalam situs web mereka.

Karena peneliti ingin menguji beda pengungkapan IFR antara perusahaan high-tech dan non high-tech maka peneliti menggunakan uji T. Dengan hitungan IFR Index dan pengklasifikasian 19 perusahaan perusahaan high-tech dan 19 perusahaan non high-tech, hasil uji signifikan adalah sebesar 0,939. Karena pengujian menggunakan tingkat signifikansi 0,05 sehingga dapat diketahui bahwa signifikansi $>0,05(0,939>0,05)$. Hal ini dapat menyatakan bahwa pengungkapan IFR antara perusahaan high-tech dan perusahaan non high-tech tidak terdapat perbedaan.

Tidak adanya perbedaan yang signifikan antara pengungkapan IFR perusahaan high-tech dan perusahaan non high-tech salah satunya disebabkan oleh sifat pelaporan keuangan melalui internet merupakan yang kegiatan pengungkapannya masih bersifat sukarela (voluntary disclosure). Jadi pengungkapan tersebut diluar kewajiban standar Akuntansi atau peraturan mengenai pengungkapan informasi dan laporan keuangan di Indonesia dikeluarkan oleh pemerintah melalui keputusan ketua BAPEPAM No. Kep 40/PM/2003. Hal ini yang menyebabkan banyak perusahaan yang melakukan kegiatan pengungkapan sukarela pada tingkat pengungkapan sebatas wajar, baik perusahaan high-tech dan non high-tech. Hendriksen dan Breda (2000) menyatakan bahwa pengungkapan wajar adalah pengungkapan cukup ditambah dengan informasi yang dapat berpengaruh pada kewajaran laporan keuangan. Pengungkapan wajar menyiratkan suatu tujuan etika, yaitu memberikan perlakuan yang sama pada semua calon pembaca. Pengungkapan IFR yang telah dilakukan perusahaan high-tech maupun non high-tech hingga saat ini bertujuan sama yaitu hanya sebatas memperbaiki reputasi perusahaan.

\section{SIMPULAN}

Berdasarkan hasil penelitian yang telah dilakukan, dapat disimpulkan bahwa Indeks pelaporan keuangan melalui internet yang terdiri dari empat komponen yaitu isi, ketepatan waktu, teknologi dan dukungan pengguna dimana pengungkapannya tidak terdapat perbedaan antara perusahaan high-tech dan non high-tech. Hal ini terbukti dengan dari hasil pengujian T. Dengan hitungan IFR Index dan pengklasifikasian 19 perusahaan perusahaan high-tech dan 19 perusahaan non high-tech, hasil uji signifikan adalah sebesar 0,939. Karena pengujian menggunakan tingkat signifikansi 0,05 sehingga dapat diketahui bahwa signifikansi $>0,05(0,939>0,05)$. Hal ini dapat menyatakan bahwa pengungkapan IFR antara perusahaan high-tech dan perusahaan non high-tech tidak terdapat perbedaan.

\section{KETERBATASAN}

Keterbatasan yang terdapat pada penelitian ini adalah:

1. Pada penelitian yang telah dilakukan terdapat unsur subjektifitas peneliti pada saat melakukan tahap check list item-item pada kriteria pengungkapan IFR.

2. Kelompok perusahaan yang dipilih sebagai sampel penelitian ini hanya terbatas pada 38 perusahaan yang terdaftar di IDX pada kuartal pertama 31 
Maret 2011 diantaranya 19 perusahaan high-tech dan 19 perusahaan non high-tech.

3. Dilihat dari sifat pelaporan, IFR masih bersifat sukarela (voluntary) sehingga perusahaan yang melakukan pelaporan secara sukarela hanya sebatas pengungkapan wajar.

4. Indeks pengukuran IFR yang digunakan hanya terbatas pada empat kriteria yaitu content, timeliness, dan technology, user support.

\section{DAFTAR PUSTAKA}

Abdelsalam, O.H., El-Masry, Ahmed. 2008. "The Impact Of Board Independence And Ownership Structure On The Timeliness Of Corporate Internet Reporting Of Irish-Listed Companies". Managerial Finance. Vol. 34 No. 12, 2008 pp. 907-918.

Almilia, Luciana Spica. 2009. "Analisa Kualitas Isi Financial And Sustainability Reporting Pada Website Perusahaan Go Publik Di Indonesia". Seminar Nasional Aplikasi Teknologi Informasi 2009 (SNATI 2009). Yogyakarta.

Ashbaugh, H., K. Johnstone, and T. Warfield. 1999. "Corporate Reporting on the

Internet”. Accounting Horizons. 13(3): 241-257.

Ghozali, L.2007. Aplikasi Analisis Multivariate dengan Program SPSS. Badan Peneliti Universitas Diponegoro. Semarang.

Hargyantoro, Febrian. 2010. "Pengaruh Internet Financial Reporting Dan Tingkat Pengungkapan Informasi Situs web Terhadap Frekuensi Perdagangan Saham Perusahaan”. Fakultas Ekonomi Universitas Diponegoro. Semarang.

Lymer, A. 1999. "Special Section: The Internet and Corporate Reporting in Europe”. European Accounting Review. Vol. 9, pp. 287-396.

Williams, S. Mitchell. 2001."Is Intellectual Capital Performance and Disclosure Practices Related?". JIC 2,3 hlmn. 192-202.

Xiao, J. Z., H. Yang and C. W. Chow. 2004. "The Determinants and Characteristics of Voluntary Internet Based Disclosures by Listed Chinese Companies". Journal of Accounting and Public Policy 23. pp. 191-225. 
